the sun at the time of totality, and that the failure to obtain observations was disastrous from Lockyer's point of view. But in another place, page 245, it is, on the contrary, remarked that Lockyer found strong support for his dissociation hypothesis in the results of the 1875 eclipse observations.

A brief statement of the facts relating to this eclipse may serve to remove the confusion to which these conflicting passages may give rise.

The Committee of the Royal Society which organised the expedition decided to divide it into two sections, one of which was to proceed to Siam, while the other was to establish itself in Camorta, one of the Nicobar islands. When it appeared that Lockyer could not leave England at the time, owing to other duties, I was appointed head of the whole expedition so long as it remained united, while Meldola was to be leader of the Camorta section after their separation. It was this latter division that met with bad weather, the sky in Siam being cloudless. The results of the expedition were worked out jointly by Lockyer and myself and were published in the Transactions of the Royal Society (1878, Part 1). The photographs showed the calcium lines $\mathrm{H}$ and $\mathrm{K}$, as well as some hydrogen lines at the base of the corona, but no other metallic lines.

Yeldall, ARTHUR SCHUSTER.

Twyford, Berks.

Sir Arthur Schuster's letter gives interesting information about the 1875 eclipse, which the biography of Sir Norman Lockyer (for the relevant portions of which I am responsible) might well have included. It is not made clear there that the British expedition divided into two sections : apparently I assumed that Camorta was in Siam !

I. have no reason to think, however, that there is any material inaccuracy in the passages referred to, although I have not now access to the papers before me when writing. Certainly the passages are not conflicting. The first states that Meldola, who was I ockyer's regular assistant, had a special programme of work arranged for him; that the expedition was fruitless through clouds, although other parties were better favoured; and that the misfortune was disastrous for Lockyer, who was left to develop his ideas without the guidance of observation at a crucial point. The second passage states that he found strong support for his ideas in the results of the eclipse observations.

It is evident that observations might support existing ideas without giving guidance for future development-which is just what occurred in this instance. What Sir Arthur Schuster makes clear, and is not stated in the biography, is that the better favoured other parties included a section of the British expedition.

Imperial College of Science and Technology,

$$
\text { Nov. } 16 .
$$

\section{Combustion of Acetylene.}

In Nature of Nov. 16, p. 761, Messrs. G. B. Kistiakowsky and $\mathrm{S}$. Lenher announce that they have recently demonstrated that "The oxidation of acetylene by oxygen proceeds at $250^{\circ}-315^{\circ}$ through the stages of glyoxal, formaldehyde, formic acid, carbon dioxide, and water" according to the scheme :

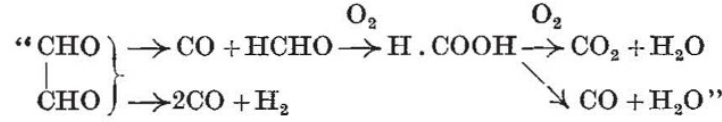

$$
\begin{aligned}
& \text { No. 3135, VoL. 124] }
\end{aligned}
$$

and that "All these reaction products have been isolated".

So long ago as 1905 , in a paper entitled "The Combustion of Acetylene ", by Mr. G. W. Andrew and myself (Jour. Chem. Soc., 87, pp. 1232-1248) embodying the results of a detailed experimental study of the subject, and particularly of the interaction between $250^{\circ}$ and $350^{\circ}$ of various mixtures of acetylene and oxygen in the ratios $2: 1,1: 1,2: 3,1: 2$, and $1: 3$ respectively -in the course of which polyglycolide $\left(\mathrm{C}_{2} \mathrm{H}_{2} \mathrm{O}_{2}\right)_{x}$ had been detected, and both formaldehyde and formic acid isolated and identified-the following statements summarising the matter appeared : "Experiments on the slow combustion of acetylene prove that carbon monoxide and formaldehyde simultaneously arise at an early stage of the process, probably as the result of the decomposition of an unstable product $\mathrm{C}_{2} \mathrm{H}_{2} \mathrm{O}_{2}$, such, for example, as $\stackrel{\mathrm{C} . \mathrm{OH}}{\mathrm{C} . \mathrm{OH}}$. The production of formaldehyde certainly precedes that of steam. The whole process may, we think, be represented by the following scheme :

$$
\begin{aligned}
& \underset{\mathrm{C} . \mathrm{H}}{\stackrel{\mathrm{H}}{\mathrm{C}}} \rightarrow\left[\begin{array}{l}
\mathrm{C} . \mathrm{OH} \\
\ddot{\mathrm{C}} . \mathrm{OH}
\end{array}\right] \rightarrow \underset{\dot{\mathrm{H}}}{\mathrm{CO}+\mathrm{H} \cdot \mathrm{C}: \mathrm{O}} \rightarrow \underset{\dot{\mathrm{H}}}{\mathrm{HO} . \mathrm{C}: \mathrm{O}} \rightarrow \mathrm{HO} \cdot \mathrm{C}: \mathrm{O} \\
& \overbrace{\left(2 \mathrm{CO}+\mathrm{H}_{2}\right)} \\
& 1 \\
& \overbrace{\mathrm{CO}+\mathrm{H}_{2}} \overbrace{\mathrm{CO}+\mathrm{H}_{2} \mathrm{O}} \overbrace{\mathrm{CO}_{2}+\mathrm{H}_{2} \mathrm{O}}
\end{aligned}
$$

Below the ignition point the formic and carbonic acids produced at stages 3 and 4, respectively, break down, forming steam and oxides of carbon, whilst above the ignition point the formaldehyde produced at stage 2 (or possibly also the dihydroxyacetylene at stage 1 ) is resolved into carbon monoxide and hydrogen," and further, that " the initial stage of the combustion involves the formation of an oxygenated molecule $\mathrm{C}_{2} \mathrm{H}_{2} \mathrm{O}_{2}$. . . which rapidly breaks down to carbon monoxide and formaldehyde, the last-named product being subsequently burnt, through formic and carbonic acids, to a mixture of $\mathrm{CO}, \mathrm{CO}_{2}$ and steam ".

It was also found that "there is little to choose between the rates of combustion observed with mixtures corresponding to $2 \mathrm{C}_{2} \mathrm{H}_{2}+\mathrm{O}_{2}$ and $\mathrm{C}_{2} \mathrm{H}_{2}+\mathrm{O}_{2}$, respectively, below the ignition point. An excess of oxgyen over and above an equimolecular proportion always retards the process."

While the recent experiments of Messrs. Kistiakowsky and Lenher have led them to adopt practically the same view regarding the mechanism of the combustion as we published twenty-four years ago, the results of our then experiments can scarcely be reconciled with their statement that " in packed vessels .. a heterogeneous oxidation direct to carbon dioxide and water takes place". We found that, on continuously circulating a $\mathrm{C}_{2} \mathrm{H}_{2}+3 \mathrm{O}_{2}$ mixture in a closed circuit comprising (i) a combustion tube packed with porous porcelain maintained at $380^{\circ}$ and (ii) apparatus for removing both condensable and water soluble products, 96.1 of acetylene burnt gave rise to 84.9 carbon dioxide, $74 \cdot 7$ carbon monoxide, $32 \cdot 6$ formaldehyde, 58.6 steam, and $4 \cdot 6$ hydrogen, reckoning all products as gaseous and occupying the same volume at the same temperature. From this it was deduced that of the total formaldehyde theoretically formed at stage 2 of the combustion, $4 \cdot 8$ per cent had decomposed into carbon monoxide and hydrogen, 33.9 per cent had appeared unchanged in the products, while the remaining 61.3 per cent had been further burnt, through formic and carbonic acids, to oxides of carbon and steam.

One outstanding feature of the explosive combustion of acetylene to which we then directed attention, and which distinguishes its case from that of ethylene, is 